NEW YORK, N.Y.-Access to information on biotechnology has been improved with the creation of two new databases that cover this hybrid field specifically. A third database, however, has been discontinued.

"Berkeley BioLink" is, in effect, an on-line directory, boasting all the advantages of a computerized index of biotech companies. "Biobusiness," a joint effort between database veterans Biosis and Information Access Co., allows literature searches. It is available through Dialog Information Services (Palo Alto, CA). But the business-oriented "Telegen Alert," from EIC/Intelligence, has been eliminated in favor of EIC's other biotech database, "Telegenline," which stresses research.

"Our main drive is keeping up with the private companies that are coming out," reports Deborah J. Ferris, president of Berkeley BioLink Corp. (Berkeley, CA), a subsidiary of Berkeley Venture Partners. BioLink contains information on some 390 companies focusing on biotechnology, 350 of which are privately held. (Ferris says that public companies are still being added to BioLink; she expects the total number of these firms to approach 100 once all the information has been input.)

BioLink provides information on who is doing what in biotech, for clients like major corporations, investment banks, and venture capitalists. Corporate and academic affiliations, key personnel, and areas of interest are included. In addition to completing its listing of public com-

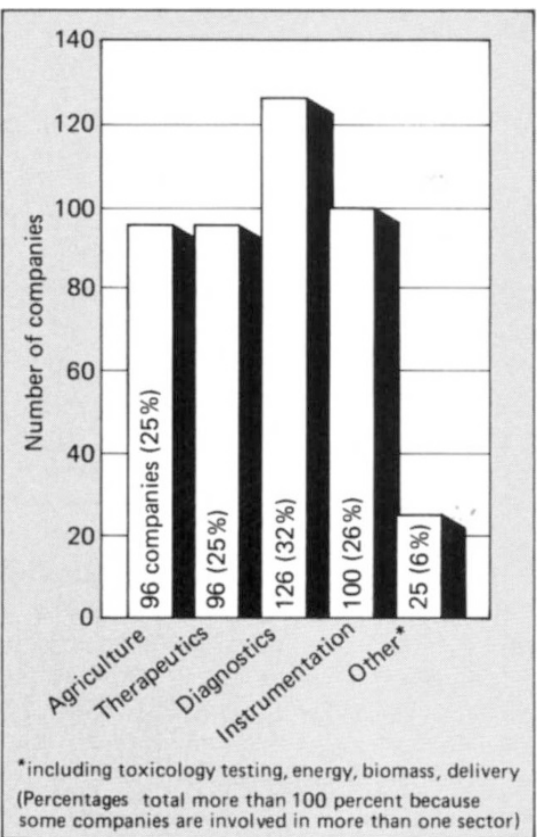

panies, BioLink is beginning to input research strengths of universities, starting with 11 schools.

BioLink categorizes companies into five groups (see chart). Ellen Feeney, a research analyst for the company, notes that the database is weighted toward private firms, a large number of which start out in the diagnostics area. Because these firms tend to add therapeutics projects as they grow, she predicts that this will be the largest growth category over the next year. Conversely, she believes that most of the companies that intend to produce instrumentation have already moved into this field.
BioLink is currently offered only as a service to clients, but Ferris plans to provide much of the database on-line eventually. Some of the information now on BioLink is proprietary, so many of the details will have to be excised for the public version.

Another new database, this one called Biobusiness, began this past summer as File 285 in the Dialog system (at a cost to the user of $\$ 117$ per connect hour). Stressing the business applications of biological and biomedical research, it covers four broad subject areas: agriculture, biotechnology, food and beverages, and pharmaceuticals. The database monitors over 1,000 publications in an effort to provide information to help users predict which research areas have the most potential for commercial growth. It began with some 16,000 records dating back to the beginning of 1985 , and will be updated monthly.

One database purveyor that is consolidating, however, is EIC/Intelligence (New York, NY). Its Telegen Alert (carried by subscription through the Dialcom network) failed to attract enough users, so it has been discontinued. According to EIC's Darren Saunders, some of Telegen Alert's contents will be added to Telegenline. Available through Dialog as File 238 (at \$95/hour connect fee), Telegenline stresses biotech research over business, and has information dating back to 1972. Telegen Alert users will miss its twice weekly updates; Telegenline is updated monthly. -Arthur Klausner

\title{
COMATI SIDATE
}

\section{ALFACEIIS CANCER CURE: HOPE OR HYPE?}

New York, N.Y.-Alfacell (Bloom- did indeed review the records of the field, $\mathrm{NJ}$ ), a small, relatively obscure development-stage company, believes it has a cancer cure. So do a lot of investors: the stock bounded from around $\$ 12$ to $\$ 23$ on April 23 , just after the company's public relations firm, Alan W. Bell (New York), issued a press release claiming that "clinical studies are ongoing and...prestigious investigators will be visiting the site of the trials in the Dominican Republic," The stock is back to about $\$ 12$ and the investigators never went. But according to Kuslima "Tina" ShogenAlfacell's chief operating officer, chief financial officer, vice president for scientific affairs, and major stock holder-one of these investigators trials.

Not all members of the financial community are believers, however. One corporate executive, who prefers to remain anonymous, says that the company is over-promoting itself; others claim that the company is manipulating the market with its frequent press releases. Alfacell has had a run-in with the Food and Drug Administration (FDA), and rumors of takeovers and short selling by insiders have created a volatile atmosphere on Wall Street.

Alfacell's anti-tumor drug is called Pannon (formerly NSTT, for nonspecific tumor toxic agent). Pannon's composition is a well-guarded secret: the only description of the compound is that is derived from living animal donor tissue. Shogen and Emil Szebenyi, Alfacell's president, began work on NSTT in 1971 when both were at Fairleigh Dickinson University (Rutherford, NJ). Ten years later they founded Alfacell, based on the belief that they had isolated a compound which cures certain forms of cancer.

Clinical trials on terminal cancer patients began in the Dominican Republic in October 1984. The FDA claims that Alfacell shipped Pannon to the Dominican Republic illegally. Shogen says that the Dominican Republic requested that the clinical trials be conducted there, so the FDA's 